\title{
Education Leadership An Analysis
}

GLENN R. SNIDER

Till a man can judge whether they be truths or no, his understanding is but little improved, and thus men of much reading, though greatly learned, but may be little knowing.

-Locke

Contemporary american society, faced with the problem of $C$ providing leadership in a swiftly changing world, is likely to be successful in this effort to the degree that its basic institutions are able to adapt readily to the multiplicity of demands which impinge upon them from all sides. Not the least of these institutions is the public school. The contribution which Education is to make to the achievement of a democratic society capable of surviving in today's world must be the major concern of all those who labor in the public education enterprise. The achievement of "The Great Society," in which education is destined to play a major role, accents its importance in the decades ahead. The relationship of educational leadership to the effective discharge of this responsibility deserves the attention of all who are interested in public education and the welfare of the nation.

The role of educational leadership in American Education has been analyzed by many. It is the purpose of this paper to indicate some major weaknesses in the level of much leadership in the educational institutions of the nation; to suggest the negative impact of this leadership on the school's contribution to the achievement of our societies' recognized goals; to point out the dangers inherent in administrative theorizing unattached to a political, moral, and ethical value structure; and to submit an approach to the improvement of educational leaders in service.

Glenn R. Snider is Professor of Education, University of Oklahoma, Norman. 


\section{Courageous Leadership Needed}

It is the moral responsibility of leadership to help provide the insight and understanding which will cause people to recognize and face the basic issues and problems in education which cry for solution. The late president, John F. Kennedy, stated in November of 1960, "I run for the presidency of the United States because it is the center of action and, in a free society, the chief responsibility of the president is to set before the American people the unfinished business of our country." 1 The educational leader must do no less regarding the unresolved problems and issues of education.

The role of the school principal or superintendent in the resolution of conflict and tension in a professional staff or community may often be that of effectively mediating the issues and problems; but occasionally it may even be that of provoking conflict at certain points in order to have significant and pressing issues discussed and analyzed under a set of conditions which appear to enhance their resolution. In pursuing such a course, the educational leader must place foremost in his set of priorities the matter of educational purposes achievement and must evaluate his course of action on the degree to which it contributes to these goals. That he should realistically appraise the obstacles which must be faced and gauge the degree of their difficulty is evident. If expediency is a low priority item in his value structure, however, he will be deterred only when it appears that something is not possible in a given situation.

It is fair to state, however, that many educational leaders who believe in democratic values and leadership, and who possess the courage and perception to identify situations in which specific action should be taken to implement purpose do not do so. They simply lack confidence in their ability to create conditions which will contribute toward the resolution of such controversy.

This same leadership must also recognize the major problem areas in which conflict and tension exists and help create the climate and set of conditions to make possible the intelligent consideration that must precede attempted solutions. The creation of this atmosphere is indeed a difficult task in many communities.

\footnotetext{
1 Theodore H. White, "One Wished for a Cry, a Sob . . Any Human Sound," Life (November 29, 1963), p. 32E.
} 


\section{The Principalship Is Crucial}

The community arena is not always the most difficult field in which the educational leader must function, although this is often the case in highly pluralistic communities. In thousands of school districts over the country, the superintendent of schools also has the basic responsibility of providing effective leadership for all of the professional members who staff the schools of the district. Within the individual elementary and secondary schools of the district, however, the principal must play the major leadership role. It has often been said that most of the significant improvements and challenging practices in education are developed through the exercise of leadership at the building level. The school program, therefore, often develops or remains stagnant in relationship to the competence and influence of the principal.

It is unrealistic to expect the principal or the superintendent to function in the absence of conflict and controversy. If this assumption is accepted, the implication is clear that individuals holding either position must become effective in dealing with discord and conflict. This observation should have major implications for educational leadership. If so, superintendents and principals must become skilled and knowledgeable in those proficiencies which encourage and elicit extensive, intelligent participation and collaboration from individual members of a professional staff and a community. Providing the kind of leadership which respects the integrity and dignity of individuals and recognizes the intellectual contribution which many of them are capable of making, becomes a difficult task indeed. The task is further complicated when it is known that many educational workers have had no experience in schools or school systems which foster this kind of contribution.

\section{Basic Human Values Must Be Taught}

When it is realized that the individual classroom practitioner is responsible for providing opportunity for the development of sound pupil understandings and attitudes regarding many of the areas of conflict and tension in America and in the world, the overall implications of effective democratic leadership are more easily understood. It is in the elementary and secondary school classrooms of the nation that the biases, prejudices, and intolerance of a future generation may be averted. The efforts to reduce these destructive attitudes and behaviors rest on basic moral and ethical values which 
have long formed the foundation of American political and social democracy: the importance and dignity of the individual personality, truth, equality of opportunity, justice, freedom, liberty, moral responsibility, brotherhood, cooperation among equals, the concept that social institutions are servants of mankind, and the belief that the application of reason is the best way to resolve problems. $^{2}$

Is it any less appropriate to rest the provision of leadership on these same values? To do otherwise makes leadership the major contributive force for man's dehumanization.

\section{LEADERSHIP WITHOUT GUIDELINES}

One of the major burdens which segments of the public education enterprise must often bear is that of inadequate, unimaginative, non-stimulative, and even offensively authoritarian leadership from the top administrative positions. Many boards of education in seeking replacement of superintendents, attempt to find individuals who will, in their words, provide strong, responsible, business-like administrative leadership with definite assurance from the policy making group that it will back him up as he "runs the school." In turn, the superintendent often establishes the same kind of expectation with regard to the principal. It rarely occurs to most school boards and many superintendents to discuss or describe the manner in which the new professional leader shall provide leadership nor to suggest principles which should guide his behavior as this responsibility is discharged.

In the absence of such counsel from a governing board, however, it is likely that the administrative behavior of the newly employed school administrator is determined chiefly by his concept of leadership and the philosophical framework within which it should be provided. The thesis advanced here is that a high percentage of those individuals now practicing administration in the public schools and institutions of higher learning in the nation provide a quality and a brand of leadership for their schools which does not contribute significantly to the achievement of the purposes for which the institutions exist and is in fact inconsistent with the

\footnotetext{
${ }^{2}$ Educational Policies Commission, Moral and Spiritual Values in American Democracy, Washington, D.C., The National Education Association, 1951, pp. 17-34.
} 
political, philosophical, and social framework of the American democratic society.

Much leadership of this type actually serves as a severe deterrent to the accomplishment of legitimate purpose by the schools involved. In other words, the consequences of educational leadership are often not positive, or even partially positive, in accomplishing institutional purposes. They may chiefly be negative providing appraisal is made with regard to the degree of purpose attainment. Unfortunate indeed is the lot of the school forced to function under the substantial handicap of predominately negative leadership. The net result of such leadership is often a demoralized professional staff; inappropriate and inadequate understanding of education and its needs, accomplishments, and potential by the community; insufficient financial support for the school program; sterile leadership at other levels in the institution or school system and an educational program which is not characterized by high quality and challenge for those who should be its beneficiaries. Operating from his status position the school administrator may thus, and often does, "sink to the depths of political opportunism, selfish manipulation, or autocratic rule."3

\section{Education Re-Made in THE LeadeR's Image}

The net result of the ministration of an educational leader of the latter type is often discovered after a few years by carefully appraising both tangible and intangible evidences in the individual school, school system, college, or university. In an effort to remake the institution or school system in the leader's image, often on the invitation of the governing board, the independent contributive minds are encouraged to leave, to limit the sphere of their activities, or are actually subjugated. The program and educational processes are remade or realigned according to the thinking of the administrator. These changes are often forthcoming either by administrative edict or by a systematic utilization and perversion of so-called democratic process. The ethical and moral implications are more significant with regard to the latter than the former.

\footnotetext{
${ }^{3}$ Cooperative Program in Educational Administration, Middle Atlantic Region, Decision Making and American Values in School Administration. New York: Bureau of Publications, Columbia University, 1954, p. 7.
} 
Leadership Consistent with a Democratic Society

Many students of American education and history contend that the public school system has the responsibility for producing an educated electorate which will make political democracy possible. This means more than a literate populace. The teaching and leadership provided in the American school should reflect this purpose in both theory and practice and furnish the necessary opportunities which may permit it to succeed. The classroom teacher must see his major role as that of assisting members of the classroom group to realize their unique potentialities. The educational leader must perceive his chief role as that of providing imaginative planning, coordination, and stimulation in releasing the abilities and potentialities of the professional group with whom he works so that the goals and purposes of the educational enterprise may be achieved in high degree. In fact, a highly logical basis by which to determine the quality of leadership of an institution is to appraise it in terms of the degree to which these functions are effectively discharged within the framework of the value structure previously described.

Professional educators feel increasingly that leadership is a responsible role to be achieved in order to reach agreed upon purposes of the group rather than an "executive duty" to be discharged by one who has had the honor of leadership conferred upon him. The nature of the control pattern of our institutions is such, however, as to make likely the continuance of status positions from which leadership will be provided. The major concern, therefore, is to develop and produce leaders who will view leadership responsibility as functioning within a democratic value structure and who are effective in providing leadership in the implementation of these values.

\section{Other Values of Leadership}

When leadership carries with it specific responsibilities associated with educational administration, it then becomes essential to consider leadership as involving a set of responsibilities to be discharged. For persons occupying status leadership positions specific background necessary for the effective accomplishment of these responsibilities must be provided. For leaders who function somewhat removed from administration this consideration becomes more academic. 
Leadership is viewed by many as situational, as a set of functions, and as fluid in the sense that its effectiveness is not persistent in the absence of imposed "status." The concept of "emerging leadership" simply means that an individual may provide leadership for a group when he assists that group in the achievement of its task and purposes and helps in the maintenance of the group by aiding in the process of meeting group and individual needs. ${ }^{4}$

Educational leadership at all levels has long been characterized in high degree by the so-called traitist approach in which accent is placed on personal qualities of the leader. This approach to the provision of leadership, when combined with authority emanating from a status or prestige position, assumes that such leadership cannot only reach identified goals but that it can overcome all situations in which it must operate. Ironically enough, much leadership of this type is still common in America despite the new challenges that face all social institutions in recent decades as they attempt to meet the needs of a rapidly changing society and world. An emerging education profession, however, conscious of its competence and insistent on the provision of leadership consistent with the tenets and beliefs of a democratic society, is increasingly intolerant of authoritarian leadership provided from an intrenched status position.

\section{A Unique Leadership Responsibility}

A great deal has been written in the past decade regarding administrative and leadership theory, much of it with specific reference to the educational enterprise. A number of studies have centered around the interpretation of administrator role and role expectancy as it relates to the behavior which is expected by professional staff members from educational leaders. Much less has been done, however, in analyzing the responsibility of the leader in assisting professional staff members to alter or change their existing expectations of leader behavior in accordance with recognized values. A high percentage of the teaching profession has never experienced challenging and democratic leadership from the office of either a principal or superintendent and have little understanding of what this entails.

\footnotetext{
"Morphet, Edgar L., Johns, R. L., Reller, Theodore L. Educational Admin. istration: Concepts, Practices and Issues. Englewood Cliffs, New Jersey: Prentice-Hall, Inc. 1959. p. 86.
} 
General Characteristics of Educational Leadership Programs

Public education as an enterprise has in recent decades developed into a highly complicated and complex operation which demands from its practioners the exercise of many specialized skills, knowledges, and competencies which often lie beyond the understanding of most members of the lay public which support the public school. This condition has led to the development of professional programs in our institutions of higher learning designed to prepare individuals for the many highly specialized positions now present in education. The most important of these is, perhaps, that of the school administrator.

A multiplicity of organized programs in undergraduate and graduate institutions of higher learning all over the nation operate on the assumption that it is possible to train or prepare persons to assume positions from which leadership will be provided. Among this group are numbered hundreds of institutions which operate professional programs preparing persons to become elementary school principals, secondary school principals, and school superintendents. The graduates of these professional schools assume leadership roles in the public schools and in other educational institutions and bear a major responsibility for the quality of American education.

The general characteristics of school administration programs over the nation have undergone considerable change since provisions were developed in most states for the licensing of these practioners. In general, however, most pre-service programs are based on the completion of an undergraduate program of teacher education plus a graduate program which includes (a) an assortment of courses in graduate professional education, (b) specific work or courses at the graduate level in school administration, and (c) some graduate course work from other disciplines, chiefly the behaviorial sciences. Extended graduate programs based on additional work such as the commonly provided two-year professional program for school administrators as well as the Ed.D. and Ph.D. programs follow somewhat the same pattern described above but often attempt to include field experiences or internships and/or special research activity or dissertations. 


\section{What Is Missing?}

Many knowledgeable persons in education have long been concerned about these questions: What are the basic understandings, skills, attitudes, competencies, or components which appear to be necessary in the provision of high level leadership in American education? What significant knowledge is a necessary prerequisite to the effective discharge of his leadership responsibility by a school administrator? To what degree is the total personal equipment of the practioner pertinent to the successful performance of his role as an educational leader? Do pre-service programs for educational administrators adequately provide for the inclusion of most significant components of leadership preparation? Does the preoccupation of these pre-service programs with the development of knowledge about education and specific skills associated with educational management generally result in the exclusion from these programs of many of the elements which relate most directly to the provision of effective leadership by the practioner? Are wellplanned experiences from the relevant behaviorial sciences available for those enrolled in leadership program?

Are programs provided at both the pre-service and in-service level based specifically on a philosophy of leadership resting on the unique nature of the American democratic society and the role of the school in the perpetuation and improvement of that society and its value structure. If so, are these programs designed to develop the understanding and operational skills for effective leadership within this framework, including its moral and ethical basis?

All institutions interested in the preparation of education leaders must be prepared to provide answers to these questions as they proceed to develop both pre-service and in-service professional programs. It is pertinent here to emphasize that the apparent dichotomy between pre-service and in-service graduate programs for educational administrators often does not exist since a high percentage of these people begin practice after completion of limited licensing programs and then must continue to do work while in service.

\section{A Current Trend}

Underlying a major change presently being undertaken in many of the major institutions of higher learning offering preparatory programs for school administrators is this concept: School administrators must provide their services within a total community 
complex which is characterized by sometimes subtle and often very practical associations with the political, social, economic, and cultural life of the area served by the school. Therefore, the program which prepares the educational leader should provide him with the opportunity to become knowledgeable about these forces which affect the life of the school, community, state, and nation in order that he may function more effectively in his leadership role.

That some merit attaches to the movement in school administration programs identified above is obvious. The speed, however, with which this idea has gained headway should cause some reflection on the part of those who are concerned with producing school administrators capable of rendering the highest quality of leadership from the status positions in the public schools. Perhaps the inadequacies of educational leadership may most frequently be attributed not so much to what the school leader does not know or understand about the educational enterprise and the community it serves, as to his inadequacy within a philosophical framework in assuming the responsibilities and discharging the functions of leadership, and his general ineptness in the proficiencies necessary for performance of administrative tasks. There is little to indicate that typical graduate offerings in the social sciences and humanities are likely to contribute substantially to the alteration of administration behavior. If geared to the achievement of this purpose they may help. Too often they have not served this purpose.

If, however, the assumption is established that school administrators may gain important knowledge and understandings plucked from offerings in these fields, and will, as a consequence, be more effective educational leaders, many will insist that important elements are still missing from the typical graduate programs which prepared them. What then is the major responsibility of preparatory institutions for the in-service improvement of school administrators? This responsibility, it is assumed, is that of using the resources of the university to provide in appropriate surroundings and circumstances important aspects of leadership preparation that were probably missing from many of the pre-service programs for school administrators.

\section{EFforts at Theory Building in Educational Leadership}

The current movement to establish a body of theory in the administration of business, industry, and government has its counter- 
part in similar efforts at theory building in administration as it relates to the educational enterprise. Griffiths synthesized effectively the major efforts at theory building in Educational Administration and described the contributions of several in this regard, particularly those of Mort and Ross, Sears, the Cooperative Program in Educational Administration of the Southern States Region at George Peabody College, and the Administration Center at the University of Chicago. ${ }^{5}$ He also analyzed attempts at administrative theorizing in areas other than Education. Interestingly enough, this able researcher also traced the place of values in theorizing about leadership and concluded that some theory building in Educational Administration was treating basic values as variables.

It is apparent that some efforts at administrative theorizing includes as a basic element attention to value structure while others do not. It was Thompson who contended when discussing the relationship of administrative theory and value: "Values capable of being attached to education and to administration will not be incorporated into the theoretical system itself; instead, the system will treat such values as variables." 6 This may be interpreted as saying that a body of educational leadership theory need not necessarily rest on a value structure since its direction and development would then be subject to pronounced limitation and inhibition. The entire range of human thought and activity must then be the area for investigation if the search for administrative theory knows no fetters. Such breadth of investigation is not apt to be fruitful in these times if the assumption is established that there is no basic value system to which major subscription is made. Search for theory not based on recognized political, moral, and ethical values would obviously not be concerned with attaining a set of conditions exemplifying the achievement of goals to which this society has given commitment. The pilfering and adapting of theoretical models in leadership and administration from other disciplines, a practice already widespread in the Education field, may be helpful, but if such theft occurs and is applied in the absence of a guiding set of values, the result may very well be disastrous.

\footnotetext{
'Daniel E. Griffiths, Administrative Theory, New York: Appleton-CenturyCrofts, Inc., 1959, pp. 47-70.

"James D. Thompson, "Modern Approaches to Theory in Administration," in Andred W. Halpin (ed.), Administration Theory in Education, Chicago: Midwest Administrative Center, 1958, p. 24.
} 


\section{Authoritarianism-A Burden}

The heritage of America and its value structure include a unique and understandably consistent conflict from earliest colonial days between the value or principle of "individual or personal rights" and authoritarianism as exerted from institutional and community status positions. By retaining authoritarianism in the operation of most institutions and organizations a curious mixture resulted. The resolution of this conflict was made more difficult by adopting certain educational practices in the 19th century from Western Europe, the vestiges of which exist to plague Education in this nation today. Many would agree with Bode as he stated three decades ago that "Our whole American life has been an unedifying mixture of authoritarianism and democracy from those earliest (Colonial) days down to the present time." 7 He further contended that:

... from the standpoint of the social order, the school becomes the institution or agency which has the special obligation of providing for the continuous reinterpretation of democracy-no authoritarian can consistently bring to light this conflict of values of standards and leave the reinterpretation to the individual-the adherent of democracy can afford to do this . . . because the "growth" of the student (or individual) is of more consequence to him than conformity to a selected standard. The second is that this belief in democracy commits him to the faith that the democratic ideal will prevail in the long run if it can be given a decent chance to be heard. 8

Dewey long ago reminded us that the denial of the democratic method of achieving social control is in part the product of sheer impatience and romantic longing for a shortcut which if it were taken would defeat its own end. ${ }^{9}$

The dominant issue, therefore, is that of authoritarianism which still looms over the institutional life of America. The patterns of industrial and economic organization, much religious organization and orientation, many visible evidences in our military and political structure at all levels, and precise line and staff arrangements in American Education accompanied by persistent authoritarian

\footnotetext{
${ }^{\top}$ Boyd H. Bode, "Ends and Means in Education or the Conflicts in our Cultural Heritage," What Is Democracy? Its Conflicts, Ends and Means. Norman, Oklahoma, Cooperative Books, 1939, p. 13.

Ibid., p. 14.

- John Dewey, "The Future of Liberalism or the Democratic Way of Change," What Is Democracy? Its Conflicts, Ends and Means. Norman, Oklahoma, Cooperative Books, 1939, p. 10.
} 
behavior, all attest to the degree to which this philosophy is imbedded in the life blood of the nation.

The early contributors to the field of school administration also played a part in establishing patterns of administrative behavior and organization which contributed strongly to solidifying hierarchy in the educational enterprise. It was Cubberly who stated that:

It is primarily the function of the superintendent to think and to plan and to lead; it is primarily the function of the principal to execute plans and to follow and to support. . . A principal should be able to sense the superintendent's policy and to carry it out without bothering him continually for details. ${ }^{10}$

Hughes recently suggested that this view of leadership is reminiscent of the Biblical injunction from Exodus 18: 25, 26 which reads "And Moses chose able men out of all Israel, and made them heads over the people, rulers of thousands, rulers of hundreds, rulers of fifties, and rulers of ten. And they judged the people at all seasons: the hard causes they brought unto Moses, but every small matter they judged themselves." 11

That the tangible evidences of authoritarianism hang like a weighted anchor around the neck of American Education, both public and private, is undeniable.

Many persons familiar with much practice in educational administration feel that attempts at providing leadership based on democratic values fail so often because well-intentioned leaders simply do not understand this philosophy of leadership or they do not possess the proficiencies needed to implement it. They fail also to recognize that many teachers and other professional personnel must receive patient assistance in accepting and participating in the processes which exemplify democracy in action. The actual emasculation of democracy in Education, however, occurs through planned perversion of the democratic process in order to create disillusionment with it and leave the way open for authoritarian manipulation. Griffiths ably illustrated this concept in a recent publication. ${ }^{12}$

\footnotetext{
${ }^{10}$ Elwood P. Cubberly, The Principal and His School, Boston: Houghton Mifflin Company, 1923, pp. 18-19.

${ }^{11}$ James Monroe Hughes, Human Relations in Educational Organization, New York: Harper \& Brothers, 1957, p. 45.

${ }^{12}$ Griffiths, op. cit., p. 111.
} 


\section{A Suggested Approach}

The concept advanced here is that most formally organized programs for school administrators, both pre-service and in-service, fail to include adequate attention to the leadership components identified below which bear so directly on the capacity of the administrator to implement effectively educational leadership based on an American democratic value structure. The development of wellconceived educational experiences designed to stablize commitment to these values and improve proficiency in these components of leadership is, therefore, proposed as a fundamental necessity if educational administrators are to behave effectively as practioners.

Significant components of leadership preparation which might well form the basis of challenging attempts to develop in-service learning situations for school principals and superintendents are: (a) an analysis of the factors effecting human relations and the study of significant problems which provide opportunity for the study of human conflict and controversy and its resolution; (b) the study of communication in the securing of social action; (c) an analysis of the processes and structure of groups; (d) developing understanding of the essential elements of the decision-making process within a democratic leadership context; and (f) acquiring an understanding of and a commitment to the political, moral, and ethical value structure of the American democratic society. ${ }^{13}$

Carefully planned efforts must be made by preparatory institutions for utilizing their total resources in providing opportunities for practioners to analyze and work with these leadership components at a time when they are engaged in administering a school or school system. The problem is two fold: the preparing institution must first develop these experiences through judicious use of available resources, and secondly it must establish cooperatively with the professional organizations and school systems the situation within which educational leaders in service will have the opportunity to work with this program under a set of conditions most likely to provoke alterations in the behavior of those who are involved. ${ }^{14}$

${ }^{1 s}$ College of Continuing Education, University of Oklahoma, A Statement of Philosophy for a Leadership Training Center. A report of the Leadership Ad Hoc Committee to the Dean of the College of Continuing Education, Norman, Oklahoma.

14 Williams, Lloyd P., "Some Reflections on the Pathology of Dehumanization." Unpublished paper, Norman, Oklahoma, November, 1964. 
As Williams remarked recently, behavior, in a primary sense, is influenced by personality structure. Personality inadequacy therefore, is a major cause for pronouncedly authoritarian behavior whether or not it emanates from status or informal leadership positions. The failure of preparatory institutions to deal primarily with the matter of the selective admission and retention element in their administrator programs may be, in the final analysis, the most significant factor in the production of authoritarians for American public education. The achievement of the goals of a democratic society are not advanced by this inadequacy.

Van Til described challenging practices in the curriculum and educational services of the school as it marshals its effort to accomplish the human relations purpose of American Education identified by the Educational Policies Commission in 1938.15 This purpose has lost none of its significance. If not achieved to a far higher degree in the American civilization, hostility and conflict may well be the leak in the dike which will assure us a minor role in the future history of the world. The general problem of improving the understanding and behavior of individuals and groups toward one another is perhaps the most crucial issue we face. The responsibility of the school and of educational leadership in the achievement of this task is apparent. If the latter is not consistent with the political, moral, and ethical value structure of this society then the goals of that society have little chance of fruition.

\footnotetext{
${ }^{16}$ William Van Til, "Challenge to America," The Role of Education in InterGroup Relations, New York: Anti-Defamation League.
} 